Article

\title{
Silverleaf (Chondrostereum purpureum) Effects on Japanese Plum (Prunus salicina)
}

\author{
Daina Grinbergs ${ }^{1, * \mathbb{D}}$, Javier Chilian ${ }^{1, *}$, Carla Hahn ${ }^{1}$, Marisol Reyes ${ }^{1} \mathbb{D}$, Mariana Isla ${ }^{1}$, Andrés France ${ }^{1}$ \\ and Jorunn Børve ${ }^{2}$
}

1 Laboratorio de Fitopatología de Frutales INIA Quilamapu, Instituto de Investigaciones Agropecuarias, INIA, Av. Vicente Méndez 515, Chillán 3780000, Chile; carlahahn@gmail.com (C.H.); mreyes@inia.cl (M.R.); marisla@udec.cl (M.I.); afrance@inia.cl (A.F.)

2 Norwegian Institute of Bioeconomy Research, NIBIO, P.O. Box 115, 1431 Ås, Norway; Jorunn.Borve@nibio.no

* Correspondence: dgrinbergs@inia.cl (D.G.); jchilian@inia.cl (J.C.); Tel.: +56-42-2206-832 (D.G. \& J.C.)

Citation: Grinbergs, D.; Chilian, J.; Hahn, C.; Reyes, M.; Isla, M.; France, A.; Børve, J. Silverleaf (Chondrostereum purpureum) Effects on Japanese Plum (Prunus salicina). Plants 2021, 10, 2777. https:// doi.org/10.3390/plants10122777

Academic Editor: Carlos AgustíBrisach

Received: 5 August 2021

Accepted: 14 September 2021

Published: 16 December 2021

Publisher's Note: MDPI stays neutral with regard to jurisdictional claims in published maps and institutional affiliations.

Copyright: (C) 2021 by the authors Licensee MDPI, Basel, Switzerland. This article is an open access article distributed under the terms and conditions of the Creative Commons Attribution (CC BY) license (https:/ / creativecommons.org/licenses/by/ $4.0 /)$.

\begin{abstract}
Silverleaf is an important fungal trunk disease of fruit crops, such as Japanese plum (Prunus salicina). It is known that infection by Chondrostereum purpureum results in discolored wood, "silvered" foliage, and tree decline. However, effects on fruit yield and quality have not been assessed. Therefore, the objectives of this study were to determine C. purpureum pathogenicity on P. salicina and the effects on physiology, fruit yield, and quality, in Chile, in 2019 and 2020. Wood samples from affected plum trees were collected in the Chilean plum productive area. Fungi were isolated by plating wood sections from the necrosis margin on culture media. Morphological and molecular characteristics of the isolates corresponded to C. purpureum (98\%). Representative isolates were inoculated from healthy plum plants and after 65-d incubation, wood necrotic lesions and silver leaves were visible. Fungi were reisolated, fulfilling Koch's postulates. To determine Silverleaf effects, xylem water potential and fruit yield and quality were measured in healthy and Silverleaf-diseased plum trees 'Angeleno'. Water potential was altered in diseased trees, and fruit yield was reduced by $51 \%$ (2019) and by $41 \%$ (2020) compared to fruit from healthy trees. Moreover, cover-colour, equatorial-diameter, and weight were reduced, and fruit were softer, failing to meet the criteria to be properly commercialized and exported to demanding markets.
\end{abstract}

Keywords: Silverleaf disease; Chondrostereum purpureum; Prunus salicina; Japanese plum

\section{Introduction}

The Japanese plum (P. salicina L.) is a deciduous stone fruit tree native to China. It is grown globally, and Chile cultivates 4520 ha, mainly 'Angeleno', 'Black-Amber', and 'Friar' cultivars. Chilean production volume is $\sim 400,000 \mathrm{t}$ (2019-2020), and Chile is the major fresh plum exporter worldwide [1].

Fungal trunk diseases have increased in recent years, in fruit, ornamental, forest, and woody species, worldwide [2]. Some of the reasons of this increase in trunk diseases in fruit crops are changes in climate, the incorporation of intensive plant production management measures such as high density plantations, the use of dwarfing rootstocks, and severe pruning, in order to accelerate plant and fruit production, which stress the plants and alter their behaviour [2-4]. Fungal trunk diseases are one of the main pathological problems for Prunus, which are affected by several fungal taxonomic groups [5]. Prunus salicina has been reported as a host of different wood fungal pathogens, such as the ones from the genera Armillaria [6], Botryosphaeria [7], Diplodia [8], Calosphaeria, Jattaea [9], Lasiodiplodia [10], Neofusicoccum [11], Phaeoacremonium, Tonignia [12], and Chondrostereum [13].

The basidiomycete C. purpureum (Pers.) Pouzar is an important wood pathogen that causes Silverleaf disease. While this fungal species has attracted considerable interest in several countries as a biological agent for woody weed control in coniferous forest plantations [13-17], it can cause severe and destructive disease in woody plants, including 
ornamental, wild, forest, and fruit crop species in some areas of the world [4,17-23]. More than 230 species are recorded as hosts of C. purpureum $[15,18,19,24,25]$, i.e., the Rosaceae family $[3,4,18,19,26-28]$ and genus Prunus, one of the most susceptible to this pathogen [18], such as P. armeniaca [29], P. avium [30], P. persica 49 [31], P. serotina [19], P. domestica [32], and P. salicina [13].

This fungus reproduces through basidiospores, which are airborne disseminated from basidiocarps, developing in dying trunks and branches of infected trees, to fresh wood wounds [33]. Mycelia grow through the xylem tissue, producing central wood discolouration [34] and subsequently occluding the vessels. In addition, the fungus produces a specific endopolygalacturonase (endoPG) enzyme, which moves to the foliage, inducing silver-greyish colour symptoms on leaves. This silver colour is usually visible several seasons after the infection [27,35]. Subsequently, the fungus kills the plant and develops purple resupinated carpophores that release spores under high humidity and mild temperatures [33].

Silverleaf is an important disease in countries such as New Zealand, the United States (Washington and Oregon) [32], Chile [3], Australia [36], France [18], Poland [37], Latvia [38], Norway [39], and other European countries [32]. It can produce severe losses in orchards, and it is the main cause of mortality in peach and nectarine in New Zealand, with losses of $8 \%$ per year [40]. In Chile, it has caused disease in different fruit crop species, such as almond, apples, blueberries, cherry, Chilean guava, nectarine, quince, pear tree, and plum $[3,4,23]$, showing silver leaves and brown central discoloration in branches and the main trunks. In blueberry, the effects of Silverleaf on plants and fruit were measured, with water potential and stomatal conductance the most affected physiological parameters, as well as a yield reduction of $40 \%$ and problems in fruit quality, such as reduction of maturation, colour, and weight [4]. Nevertheless, there is a lack of information about the effects of Silverleaf in other fruit crops.

New wood pathogens are being reported every day, and in a wider range of hosts and geographical locations $[5,9,12,17,28,41,42]$. However, little is known about their impact on fruit yield and quality. The most exhaustive research has been performed on grapevines, revealing that wood diseases are the main biotic factor limiting vineyard productivity and longevity, causing major economic losses [43].

Similar to that for other other trunk diseases, the information about Silverleaf effects on fruit crops and in Japanese plum is scarce. Therefore, the objectives of the present study were to investigate the etiology of the fungal pathogen causing foliar silvering in P. salicina in Chile, to determine its pathogenicity in plum, and to assess the effects of C. purpureum on plum physiology, fruit yield, and quality.

\section{Results}

\subsection{Chondrostereum purpureum Isolates}

Ninety-seven wood samples from Japanese plum trees showing foliar silvering (Figure 1A) and internal brown circular discolorations in transverse section (Figure 1B) (ragged, tapered cylinders in axial section), in affected branches and main trunks, were collected from 2018 to 2020. Some samples also showed other wood symptoms such as wedge-shaped and dark brown irregular discolorations, suggesting the presence of a diversity of pathogens. In 95 isolates, obtained from $98 \%$ of the wood samples, macroscopic and microscopic morphological characteristics of the colonies were consistent with those described for C. purpureum [44]. White-cottony mycelia (Figure 1C) with clamp connections grew from wood sections from the necrosis progress area, which were surface disinfected and plated on Petri plates containing acidified potato dextrose agar (APDA) (25\% PDA, acidified with $0.2 \% v / v 85 \%$ lactic acid) and water agar (WA). After 14-21 days of incubation at $25{ }^{\circ} \mathrm{C}, 52 \%$ of the isolates developed beige to light pink pseudo-basidiocarps on the edges of the plates. The fruiting bodies of most of the isolates developed hyaline, apiculate, and ovoid basidiospores, $5.3(4.7-6.8) \mu \mathrm{m} \times 3.6(3.0-4.5) \mu \mathrm{m}(\mathrm{n}=50)$. 


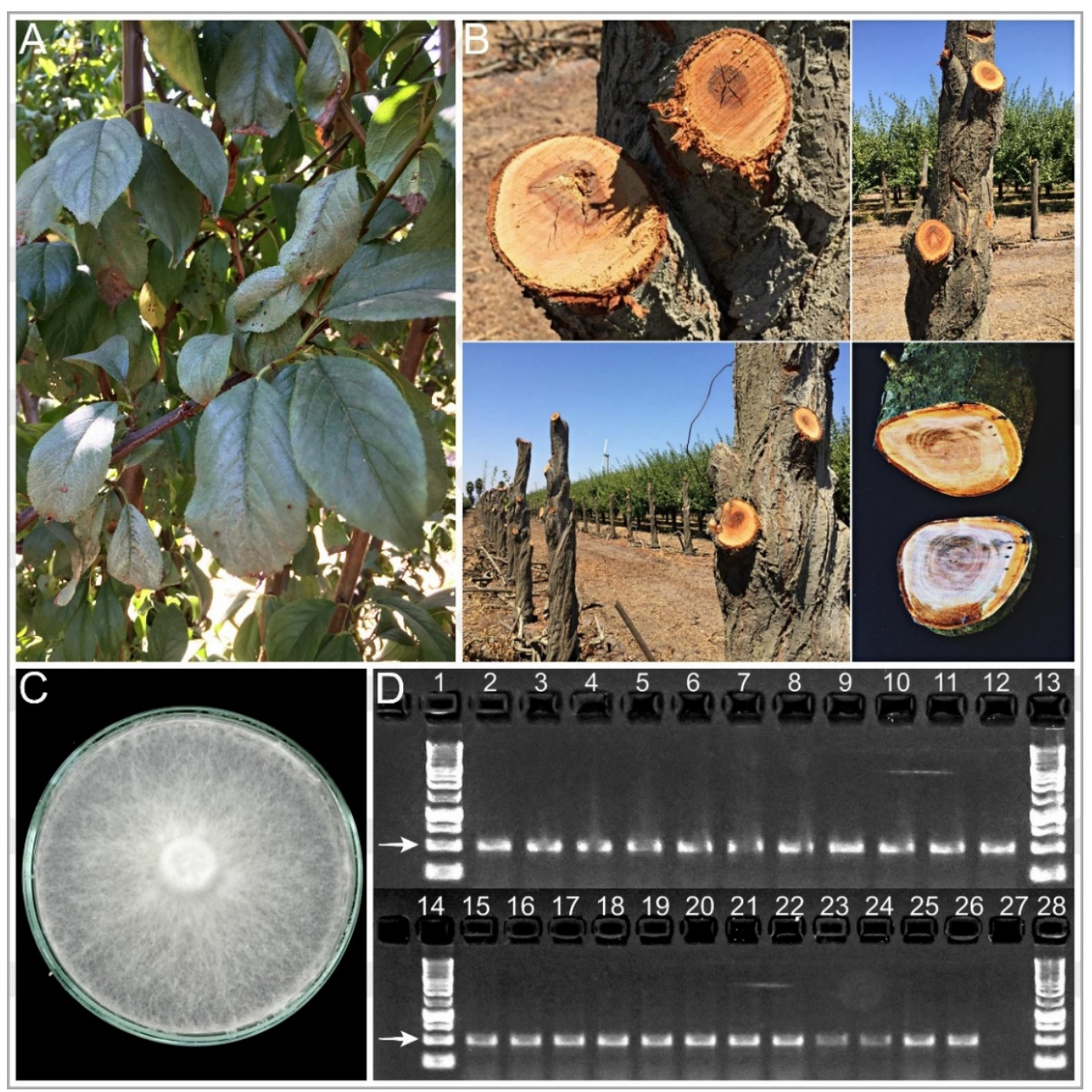

Figure 1. Silverleaf disease caused by Chondrostereum purpureum on Japanese plum in Chile; (A) foliar symptoms and (B) wood discoloration symptoms on plum trees 'Angeleno', (C) isolate HMCi7 Genbank: MW938164, and (D) Polimerase Chain Reaction (PCR) products using APN1 species-specific primers for 22 C. purpureum isolates (Lanes 2 to 11 and 15 to 26). Lane 12: positive control isolate RGM 122 GenBank: MK22253.1. Lane 27: negative control. Lanes 1, 13, 14, and 28: molecular weight standards. The white arrow indicates the fragment of interest, whose size is 500 base pairs.

Moreover, the identity of 57 isolates representing different localities and host cultivars was confirmed though DNA amplification using APN1 primers, developing intensely discrete 500-bp bands on agarose gels (Figure 1D) [14]. The internal transcribed spacer of representative isolates, selected from different host cultivars and collection localities (HMCi7; HMCi121; HMCi147; and HMCi148), was also amplified using Internal Transcribed Spacer sequence (ITS) ITS1 and ITS4 [45]. Sequences were deposited in GenBank (MW938164, MW938165; MW938166; and MW938167, respectively) (Table 1).

In $24 \%$ of the wood samples, it was possible to isolate other fungal pathogens, most of them associated with wedge-shaped and irregular dark-brown discolorations. Fungi were identified as Cytospora (12.6\%), Phomopsis (9.2\%), Schizophyllum (17.2\%), and Stereum (7.9\%) species in the Botryosphaeriaceae family $(42.8 \%)$, in addition to other fungi $(10.3 \%)$. 
Table 1. Isolate, plant host, geographic origin, DNA amplification using APN1 Chondrostereum purpureum-specific primers, and GenBank Accession number of 17 representative C. purpureum isolates, morphologically and molecularly identified in this study.

\begin{tabular}{|c|c|c|c|c|c|c|c|}
\hline \multirow{2}{*}{$\begin{array}{c}\text { Isolate } \\
\text { HMCi } 314\end{array}$} & \multirow{2}{*}{$\begin{array}{c}\text { Species } \\
\begin{array}{c}\text { Chondrostereum } \\
\text { purpureum }\end{array}\end{array}$} & \multicolumn{2}{|c|}{ Host } & \multicolumn{2}{|c|}{ Geographic Origin } & \multirow{2}{*}{$\begin{array}{c}\text { APN1 } \\
\text { Positive }\end{array}$} & \multirow{2}{*}{$\begin{array}{c}\text { ITS GenBank } \\
\text { Accession } \\
\text { Number }\end{array}$} \\
\hline & & $\begin{array}{l}\text { Prunus domestica } \\
\text { subsp. domestica }\end{array}$ & $\mathrm{D}^{\prime}$ Agen & Colbún & $\begin{array}{l}35^{\circ} 45^{\prime} 01.1592^{\prime \prime} \mathrm{S} \\
71^{\circ} 25^{\prime} 46.4889^{\prime \prime} \mathrm{W}\end{array}$ & & \\
\hline HMCi 325 & $\begin{array}{c}\text { Chondrostereum } \\
\text { purpureum }\end{array}$ & $\begin{array}{l}\text { Prunus domestica } \\
\text { subsp. domestica }\end{array}$ & D'Agen & $\begin{array}{l}\text { Sagrada } \\
\text { Familia }\end{array}$ & $\begin{array}{l}34^{\circ} 59^{\prime} 50.0820^{\prime \prime} \mathrm{S} \\
71^{\circ} 21^{\prime} 48.2976^{\prime \prime} \mathrm{W}\end{array}$ & Positive & - \\
\hline HMCi 331 & $\begin{array}{c}\text { Chondrostereum } \\
\text { purpureum }\end{array}$ & $\begin{array}{l}\text { Prunus domestica } \\
\text { subsp. domestica }\end{array}$ & $\mathrm{D}^{\prime}$ Agen & San Javier & $\begin{array}{l}35^{\circ} 38^{\prime} 54.7944^{\prime \prime} \mathrm{S}, \\
71^{\circ} 36^{\prime} 47.9340^{\prime \prime} \mathrm{W}\end{array}$ & Positive & - \\
\hline HMCi 341 & $\begin{array}{c}\text { Chondrostereum } \\
\text { purpureum }\end{array}$ & $\begin{array}{c}\text { Prunus domestica } \\
\text { subsp. italica }\end{array}$ & Reina Claudia & Chillán & $\begin{array}{l}34^{\circ} 58^{\prime} 10.7536^{\prime \prime} \mathrm{S}, \\
71^{\circ} 21^{\prime} 14.8464^{\prime \prime} \mathrm{W}\end{array}$ & Positive & - \\
\hline HMCi 308 & $\begin{array}{c}\text { Chondrostereum } \\
\text { purpureum }\end{array}$ & $\begin{array}{l}\text { Prunus domestica } \\
\text { subsp. italica }\end{array}$ & Reina Claudia & $\begin{array}{c}\text { San Rafael, } \\
\text { Maule }\end{array}$ & $\begin{array}{l}35^{\circ} 18^{\prime} 37.0044^{\prime \prime} \mathrm{S}, \\
71^{\circ} 29^{\prime} 06.5832^{\prime \prime} \mathrm{W}\end{array}$ & Positive & - \\
\hline HMCi 290 & $\begin{array}{c}\text { Chondrostereum } \\
\text { purpureum }\end{array}$ & $\begin{array}{l}\text { Prunus domestica } \\
\text { subsp. italica }\end{array}$ & Reina Claudia & Yungay & $\begin{array}{l}37^{\circ} 07^{\prime} 21.6127^{\prime \prime} \mathrm{S} \\
72^{\circ} 00^{\prime} 02.1028^{\prime \prime} \mathrm{W}\end{array}$ & Positive & - \\
\hline HMCi 249 & $\begin{array}{c}\text { Chondrostereum } \\
\text { purpureum }\end{array}$ & Prunus salicina & Angeleno & Codegua & $\begin{array}{l}34^{\circ} 01^{\prime} 12.3420^{\prime \prime} \mathrm{S} \\
70^{\circ} 41^{\prime} 50.0352^{\prime \prime} \mathrm{W}\end{array}$ & Positive & - \\
\hline HMCi 7 & $\begin{array}{c}\text { Chondrostereum } \\
\text { purpureum }\end{array}$ & Prunus salicina & Angeleno & Curicó & $\begin{array}{l}34^{\circ} 58^{\prime} 58.21^{\prime \prime} \mathrm{S} \\
71^{\circ} 16^{\prime} 37.01^{\prime \prime} \mathrm{W}\end{array}$ & Positive & MW938164 \\
\hline HMCi 340 & $\begin{array}{c}\text { Chondrostereum } \\
\text { purpureum }\end{array}$ & Prunus salicina & Angeleno & Portezuelo & $\begin{array}{l}36^{\circ} 34^{\prime} 43.9356^{\prime \prime} \mathrm{S}, \\
72^{\circ} 33^{\prime} 19.7424^{\prime \prime} \mathrm{W}\end{array}$ & Positive & - \\
\hline HMCi 121 & $\begin{array}{c}\text { Chondrostereum } \\
\text { purpureum }\end{array}$ & Prunus salicina & Black amber & Curicó & $\begin{array}{l}36^{\circ} 37^{\prime} 27.1128^{\prime \prime} \mathrm{S}, \\
72^{\circ} 00^{\prime} 27.8532^{\prime \prime} \mathrm{W}\end{array}$ & Positive & MW938165 \\
\hline HMCi 272 & $\begin{array}{c}\text { Chondrostereum } \\
\text { purpureum }\end{array}$ & Prunus salicina & Black amber & Romeral & $\begin{array}{l}34^{\circ} 57^{\prime} 17.2836^{\prime \prime} \mathrm{S}, \\
71^{\circ} 08^{\prime} 11.2560^{\prime \prime} \mathrm{W}\end{array}$ & Positive & - \\
\hline HMCi 276 & $\begin{array}{c}\text { Chondrostereum } \\
\text { purpureum }\end{array}$ & Prunus salicina & Black amber & Teno & $\begin{array}{l}34^{\circ} 52^{\prime} 39.4149^{\prime \prime} \mathrm{S} \\
71^{\circ} 05^{\prime} 19.0032^{\prime \prime} \mathrm{W}\end{array}$ & Positive & - \\
\hline HMCi 168 & $\begin{array}{c}\text { Chondrostereum } \\
\text { purpureum }\end{array}$ & Prunus salicina & Fortune & Melipilla & $\begin{array}{l}33^{\circ} 41^{\prime} 09.3696^{\prime \prime} \mathrm{S} \\
71^{\circ} 06^{\prime} 23.7960^{\prime \prime} \mathrm{W}\end{array}$ & Positive & - \\
\hline HMCi 253 & $\begin{array}{c}\text { Chondrostereum } \\
\text { purpureum }\end{array}$ & Prunus salicina & Friar & Paine & $\begin{array}{l}33^{\circ} 52^{\prime} 11.7156^{\prime \prime} \mathrm{S} \\
70^{\circ} 44^{\prime} 21.5700^{\prime \prime} \mathrm{W}\end{array}$ & Positive & - \\
\hline HMCi 148 & $\begin{array}{c}\text { Chondrostereum } \\
\text { purpureum }\end{array}$ & Prunus salicina & Larry Ann & Curicó & $\begin{array}{l}34^{\circ} 58^{\prime} 56.0352^{\prime \prime} \mathrm{S} \\
71^{\circ} 16^{\prime} 34.0896^{\prime \prime} \mathrm{W}\end{array}$ & Positive & MW938167 \\
\hline HMCi 147 & $\begin{array}{c}\text { Chondrostereum } \\
\text { purpureum }\end{array}$ & Prunus salicina & Larry Ann & Rio Claro & $\begin{array}{l}35^{\circ} 12^{\prime} 0.18936^{\prime \prime} \mathrm{S} \\
71^{\circ} 14^{\prime} 36.1140^{\prime \prime} \mathrm{W}\end{array}$ & Positive & MW938166 \\
\hline HMCi 157 & $\begin{array}{c}\text { Chondrostereum } \\
\text { purpureum }\end{array}$ & Prunus salicina & Larry Ann & Yungay & $\begin{array}{l}37^{\circ} 08^{\prime} 50.452^{\prime \prime} \mathrm{S} \\
71^{\circ} 52^{\prime} 20.673^{\prime \prime} \mathrm{W}\end{array}$ & Positive & - \\
\hline
\end{tabular}

\subsection{Pathogenicity Tests}

Healthy nursery plants were successfully inoculated with C. purpureum isolates and reproduced silver foliar symptoms (Grade 3-8) (Figures 2 and 3A,B). After the incubation period, brown central staining was visible when the inoculated branches were transversally cut (Figure 3A,C). Moreover, one of the inoculated plants, with the HMCi121 isolate, developed resupinated purple carpophores in the main trunk, above the soil level, after 20 months of incubation (Figure 3E).

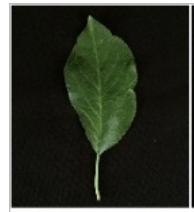

1

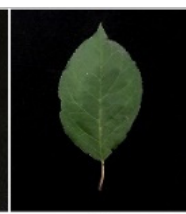

2

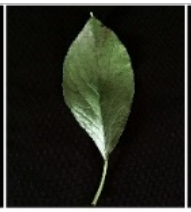

3

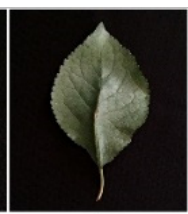

4

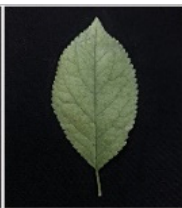

5

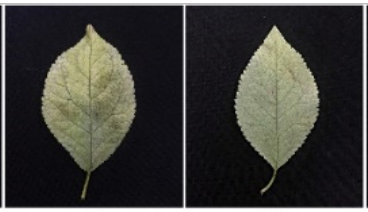

6

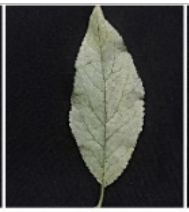

8

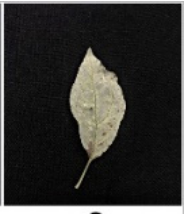

9

Figure 2. Silverleaf disease foliar symptom visual severity scale (one to nine) for Japanese plum. 1 = healthy or apparently healthy leaf, 3 = epidermis starts detaching from the mesophyll and the color is lighter than in healthy leaves, $5=$ more than $75 \%$ of the leaf epidermis is detached from the mesophyll and the leaf is beginning to look gray-silver, $7=100 \%$ of the epidermis is detached from the mesophyll and the leaf is completely white-silver, $9=$ the epidermis peels off from the leaf and the mesophyll begins to oxidize. Grades 2, 4, 6, and 8 indicate intermediate symptom severity between the previous and the following grade. 


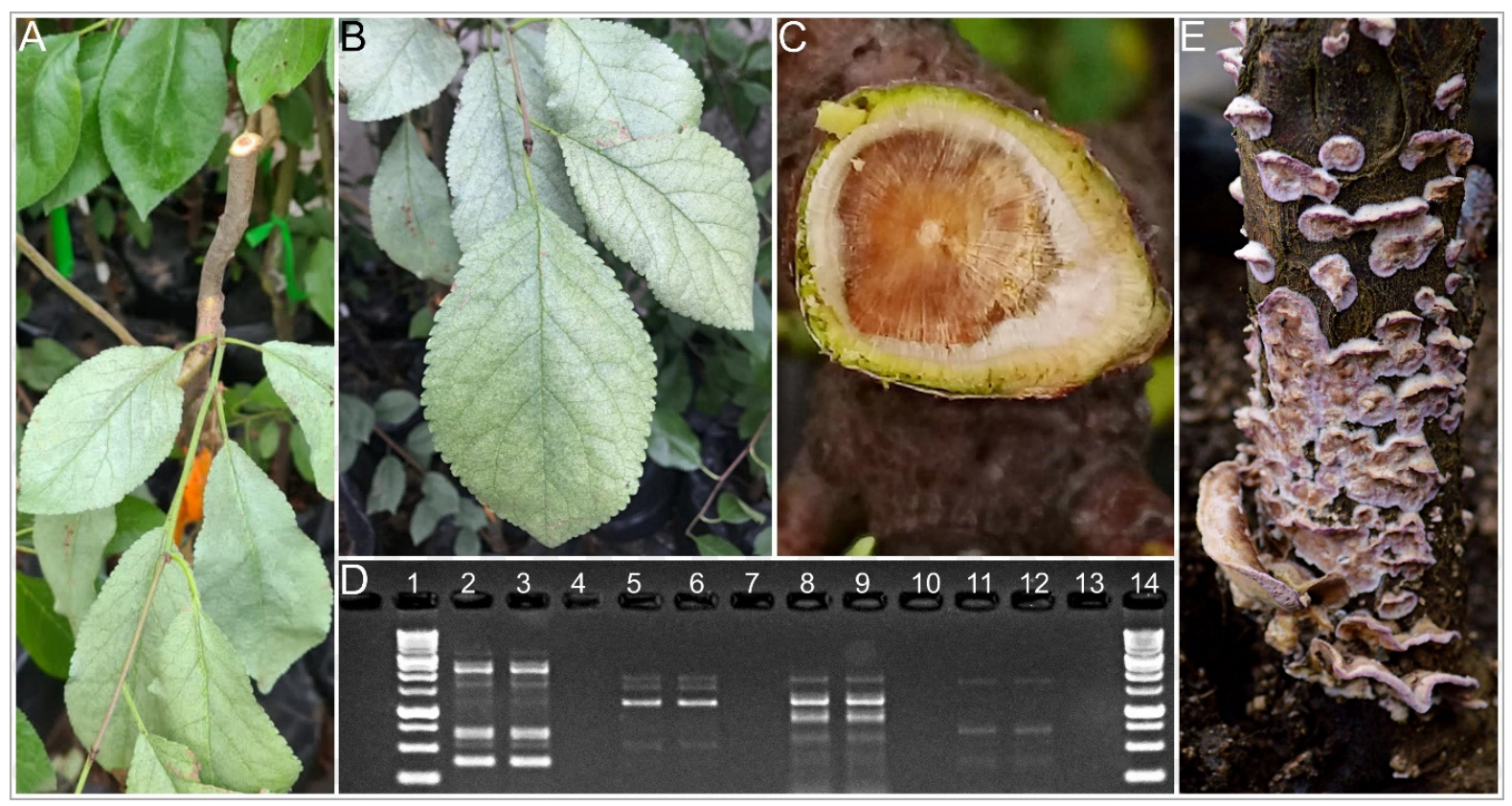

Figure 3. Pathogenicity tests of four Chondrostereum purpureum isolates on 2-year old Japanese plum plants 'Angeleno'; (A) transversal cut on an inoculated branch $20 \mathrm{~cm}$ from the inoculation point, (B) foliar symptoms, and (C) necrotic symptoms developed by inoculated plants after a 65-day incubation. (D) Chondrostereum purpureum DNA banding patterns on agarose gel, after amplification with APM22 fingerprinting markers. Lanes 2 and 3: inoculated and reisolated C. purpureum HMCi7, Lanes 5 and 6: isolated and reisolated HMCi121, Lanes 8 and 9: isolated and reisolated HMCi147, and Lanes 11 and 12: isolated and reisolated HMCi148. Lanes 4, 7, 10, and 13 are negative controls. Lanes 1 and 14: molecular weight standards. (E) Fruiting bodies of isolate HMCi121 after 20 months of incubation.

It was possible to reisolate C. purpureum from inoculated plants (100\%) on APDA, while the fungus was not reisolated from controls. The banding patterns in agarose gels, produced by DNA amplification using Sequence Characterized Amplified Region (SCAR) fingerprinting primers APM22D13 [14], were identical between inoculated and reisolated C. purpureum isolates (Figure 3D), fulfilling Koch's postulates.

\subsection{Silverleaf Effects on Plum}

To confirm the presence or absence of $C$. purpureum in symptomatic and asymptomatic plants, respectively, the fungus was detected by amplifying fungal DNA, directly from the trunk sawdust, using APN1 species-specific primers, in 2019 and 2020. A 500-bp band was reproduced in agarose gels from diseased trees, while DNA from asymptomatic ones did not reproduce the band (Figure 4). In 2020, symptoms were less severe than in 2019 (Grade 3, average), and two of the previously selected trees did not show any foliar symptoms, but they were positive for APN1 amplification. 


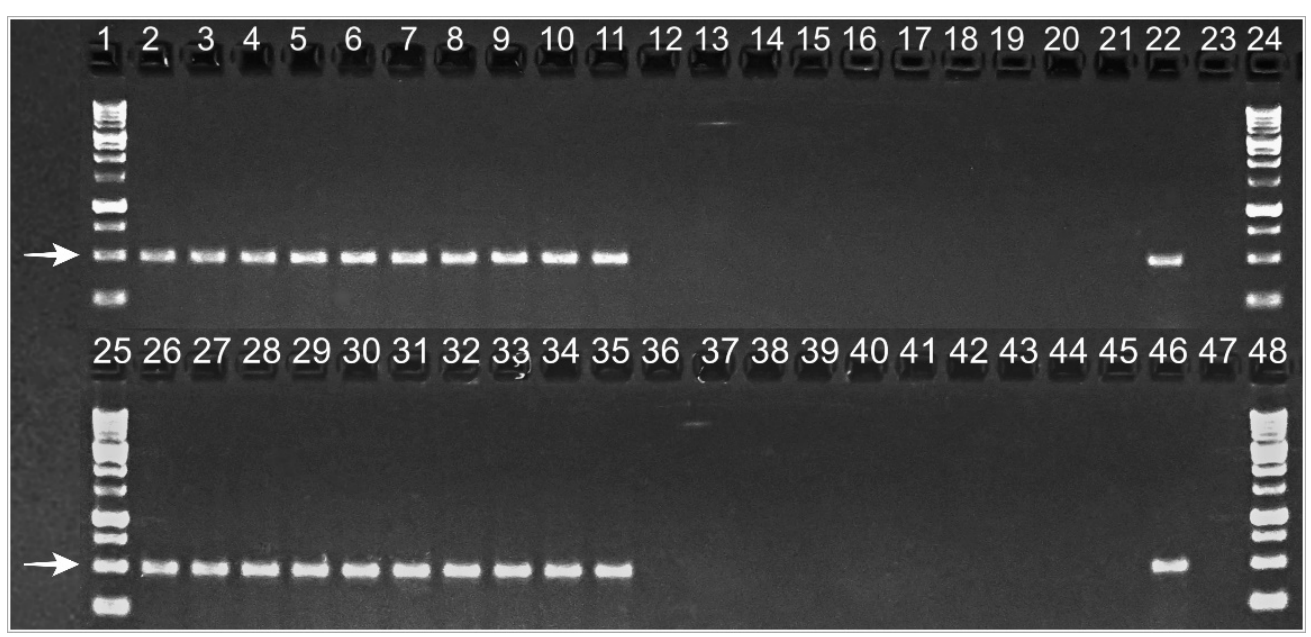

Figure 4. Chondrostereum purpureum DNA amplification using APN1 species-specific primers in Silverleaf-diseased plum plants, showing foliar symptoms (Lanes 2-11 and 26-35), and healthy ones (Lanes 12-21 and 36-45) (2019). Lanes 22 and 46: positive controls (isolate HMCi147 GenBank: MW938166). Lanes 23 and 47: negative controls. Lanes 1, 24, 25, and 48: molecular weight standards. White arrows indicate the fragment of interest, whose size is 500 base pairs.

\subsubsection{Water Potential}

Xylem potential was $19 \%$ lower in diseased plants $(-11$ bar) than in healthy ones ( -9.2 bar) in 2019 (Student's $t$-test, $p<0.0001)$. Similarly, in 2020, the water potential of diseased plants ( -12 bar) was $22.5 \%$ lower than that in healthy ones $(-9.4$ bar) (Student's $t$-test, $p<0.0001$ ) (Figure 5). It was measured a few days after harvest in both years.

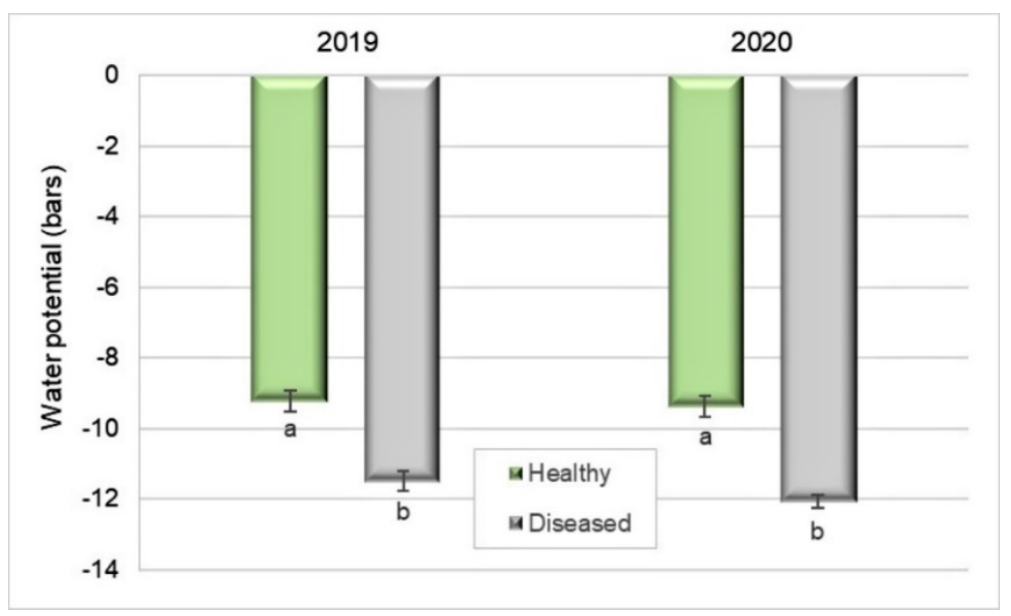

Figure 5. Water potential of leaves of healthy and Silverleaf-diseased Japanese plums 'Angeleno', based on ten replicates of two trees and five leaf samples per tree (2019) and $9 \times 2 \times 5$ (2020). Bars represent the standard error of the means, and columns with different letters are statistically different. Student's $t$-test: $p<0.0001$ in 2019 and 2020.

\subsubsection{Yield Assessment}

The total yield of the Silverleaf-diseased trees was $51 \%$ lower $(12.1 \mathrm{~kg}$ per tree) than that of healthy ones (24.8 kg per tree) (Student's $t$-test, $p=0.0001$ ) in 2019 (Figure 6). In 2020, the total yield was $41 \%$ lower ( $13.7 \mathrm{~kg}$ per tree) than that of healthy plants ( $23.5 \mathrm{~kg}$ per tree) (Student's $t$-test, $p=0.0003$ ) (Figure 6). 


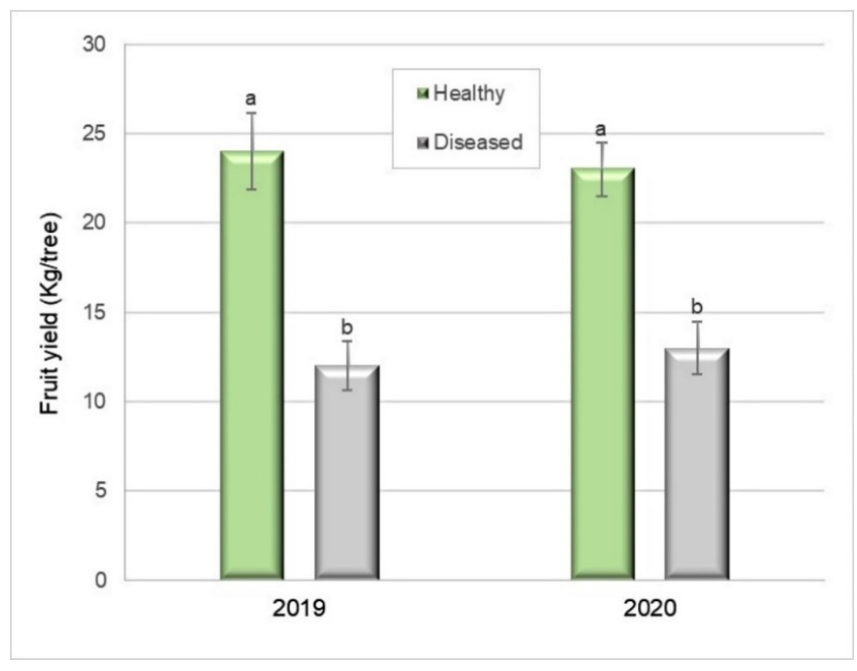

Figure 6. Fruit yield (kg) of healthy and Silverleaf-diseased Japanese plums 'Angeleno'. Ten replicates of two trees (2019) and $9 \times 2$, in 2020. Bars represent the standard error of the means, and columns with different letters are statistically different. Student's t-test: $p=0.0001$ in 2019 and $p=0.0003$ in 2020 .

\subsubsection{Fruit Quality}

In the 2019 period, fruit harvested from healthy trees had $89 \%$ cover colour, compared to $73 \%$ in diseased ones (Pearson Chi-squared test $=16.37, p=0.0001$ ). In the next season, the cover colour of fruit from healthy trees was higher than that in the previous year $(91 \%)$, while the colour of fruit from diseased trees remained similar to that in the previous year (Pearson's Chi-squared test $=18, p<0.0001)$ (Figure 7A).
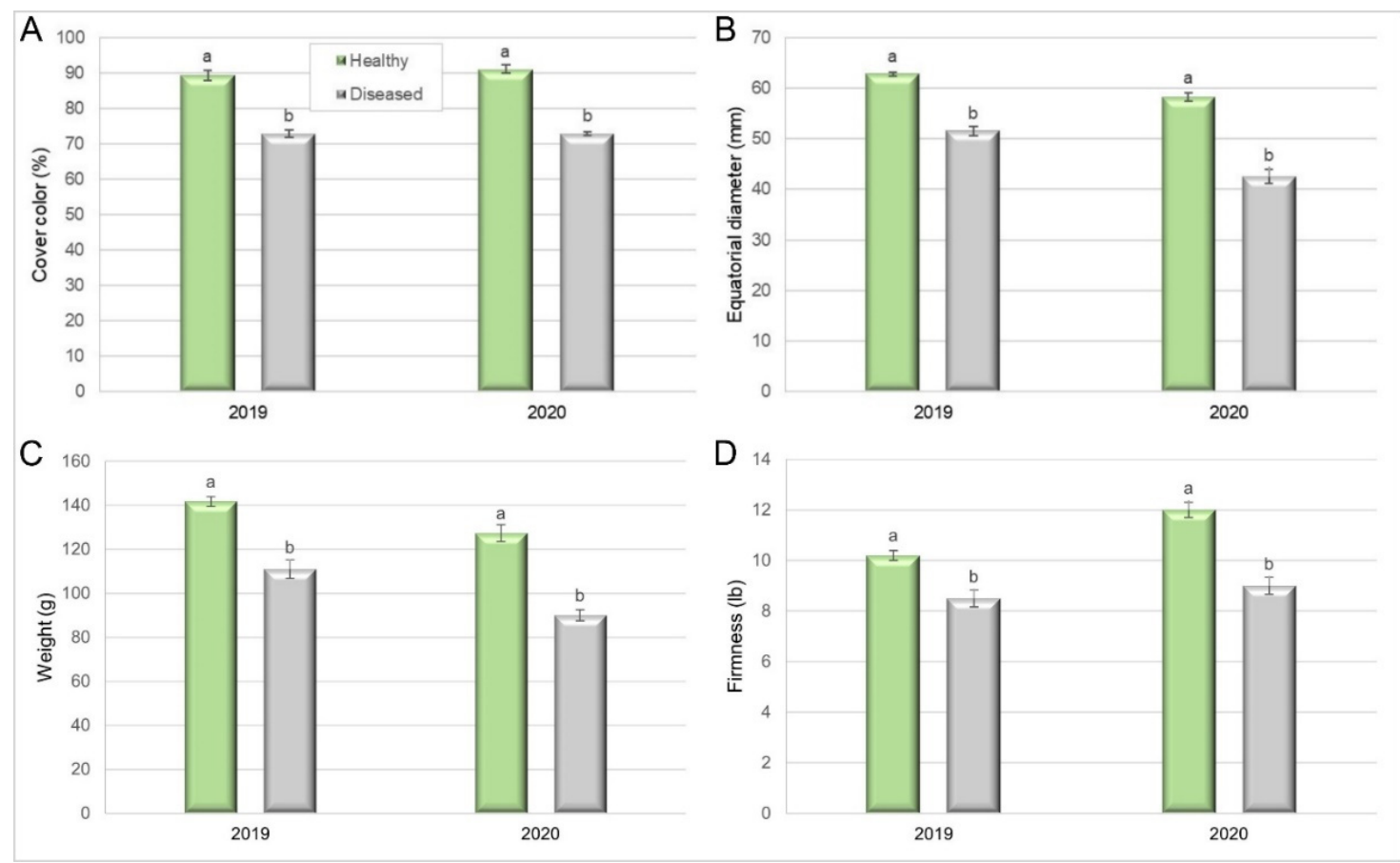

Figure 7. Quality of fruit from healthy and Silverleaf-diseased trees in a Japanese plum orchard ('Angeleno'): (A) cover color (Pearson Chi-squared test, $p=0.0001$ in 2019 and $p<0.0001$ in 2020), (B) equatorial diameter (Kruskal-Wallis, $p=0.0002$ in 2019; $p<0.0001$ in 2020), (C) individual weight (Student's $t$-test, $p<0.0001$ in 2019 and 2020) and (D) firmness (KruskalWallis, $p=0.0005$ in 2019 and $p<0.0001$ in 2020). Mean of 20 trees $\times 10$ fruit samples (2019) and $18 \times 10(2020)$. Bars represent the standard error of the means, and columns with different letters are statistically different. 
The fruit equatorial diameter was also negatively affected by the disease. In 2019, it was $62.8 \mathrm{~mm}$ in fruit from healthy trees, compared to $51.5 \mathrm{~mm}$ in fruit from diseased ones (Kruskal-Wallis, $p=0.0002$ ). In 2020, the equatorial diameter was lower than in the previous season, both for fruit from healthy trees $(58.5 \mathrm{~mm})$ and diseased ones $(42.4 \mathrm{~mm})$ (Kruskal-Wallis, $p<0.0001$ ) (Figure 7B).

Fruit individual weight was also a parameter affected by Silverleaf. In 2019, fruit harvested from healthy trees weighed $141.7 \mathrm{~g}$ compared with $111.3 \mathrm{~g}$ for diseased trees (Student's $t$-test, $p<0.0001$ ). In the next season, fruit from healthy trees weighed $127.5 \mathrm{~g}$ compared with $90 \mathrm{~g}$ for diseased trees (Figure 7C) (Student's $t$-test, $p<0.0001)$. Finally, fruit from diseased trees $(4.54 \mathrm{kgf})$ was softer than fruit from healthy ones $(3.75 \mathrm{kgf})$, in 2019 (Kruskal-Wallis, $p=0.0005)$, as well as in 2020 (5.44 kgf for fruit from diseased and $3.88 \mathrm{kgf}$ for fruit from healthy trees (Kruskal-Wallis, $p<0.0001)$ ) (Figure 7D), indicating a shorter postharvest life for fruit from diseased trees.

The other measured quality parameters $(\mathrm{pH}$, titratable acidity, soluble-solids, and background colour) were not different between fruit harvested from diseased and healthy trees (data not shown).

\section{Discussion}

In the present study, C. purpureum was successfully isolated from the necrotic margin of stained wood of Japanese plums trees showing Silverleaf foliar symptoms. The symptoms were similar to those described for other fruit hosts $[3,23,46]$. Chondrostereum purpureum is a primary invader of woody angiosperms and enters its host through a fresh wound, followed by the infection of aggressive saprobic fungi such as Trametes versicolor and Schizophyllum commune $[15,16]$. However, C. purpureum is still present in these trees and is also able to produce foliar symptoms, as was demonstrated in this study, with the symptom observation and C. purpureum molecular detection and isolation.

The isolated fungus developed white-cottony mycelia, and it was also possible to detect it directly in wood, through clear staining bands on agarose gels, when fungal DNA was amplified with APN1 species-specific primers [14]. Moreover, the Japanese plum plants inoculated with C. purpureum isolates clearly showed foliar symptoms, developing silvergreyish leaves in the inoculated branches, as well as internal wood necrosis and fruiting bodies. Reisolated fungal specimens showed the same cultural features as the inoculated ones, as well as identical banding patterns on agarose gels when SCAR fingerprinting markers [14] were used to amplify their DNA, thus fulfilling Koch's postulates.

It was demonstrated that wood diseases alter physiological parameters in different hosts $[47,48]$. Likewise, in this study, the water potential was lower in diseased plants compared to healthy ones. Similarly, in 2020, the water potential of diseased plants was lower than that in healthy ones. These differences can be explained by C. purpureum growth through the xylem tissues of the host [33], as well as from the systematic silvering of leaves [26]. During the infection process, C. purpureum produces the occlusion of tree vessels [31]. Moreover, transpiration, stomatal conductance, and leaf area decrease significantly while leaf-silvering intensity increases [26]. The resulting physiological disruption and dehydration, combined with fungal toxins, finally cause the death of the host $[21,33,49]$.

On the other hand, intensity of symptoms may change between seasons, such as in some trees in the present study. Intensity was lower in some plants, despite the presence and viability of the fungus, which was confirmed by PCR and microbiological isolation, as occurred in apple [50], where the reversion of foliar symptoms was first described. Damaged wood on the branches and trunk is the battleground of microorganisms, pathogens, and endophytes. While vascular tissue is being destroyed by pathogens [51], some endophytic microorganisms could be acting as their antagonists and/or inducing plant resistance [50] and thus modulating disease expression [52].

Foliar symptoms remained similar in their intensity (Grades 3-6 on the severity scale) (Figure 2) in most of the diseased analysed trees (95\%) during 2019 and 2020. In 2019, a reduction of $51 \%$ in total fruit weight was recorded in Silverleaf-diseased plants com- 
pared to healthy ones. Moreover, in 2020, the reduction was $41 \%$. The fungal pathogen inhabiting the vessels and necrotic tissue affected the number and weight of fruits per tree. Similarly, fruit yield decreases due to several wood pathogens [41]. The results were consistent with yield assessments performed in other fruit crops in Chile, such as apples and blueberries $[4,53]$. Although there are authors who point out yield losses due to the damaging effects of $C$. purpureum infections in stone and pome fruits $[18,26,36,40,44]$, as well as blueberries [4], as far as we are concerned, this is the first record about yield losses in Japanese plum related to the detrimental effects caused by C. purpureum.

Regarding fruit quality, our results showed that important quality components such as fruit weight, cover colour, equatorial diameter, and firmness were influenced by Silverleaf disease. Similar results were reported by $[25,26]$ in apple orchards, with smaller and lower numbers of fruit, reduced colour, and an increased incidence of physiological damage such as a water core, short post-harvest storage, and softening of fruit. Furthermore, [27] stated that the spread of $C$. purpureum in woody tissues and the loss of photosynthetic capability eventually leads to tree death.

In conclusion, our work has demonstrated that C. purpureum alters physiological parameters such as the water potential of Japanese plum trees and negatively impacts fruit yield and quality. The latter can decrease the orchard productivity and, moreover, the fruit harvested from diseased trees does not meet the requirements to be properly commercialized or exported to demanding markets.

\section{Materials and Methods}

\subsection{Collection of Samples}

Collections of wood samples (97) from plum trees showing foliar silvering and internal wood discoloration symptoms were conducted in the Chilean Japanese plum productive area, from the Metropolitana Region $\left(33^{\circ} 42^{\prime} 16.11^{\prime \prime} \mathrm{S}, 70^{\circ} 59^{\prime} 11.82^{\prime \prime} \mathrm{W}\right)$ to the Nuble Region $\left(36^{\circ} 37^{\prime} 24.98^{\prime \prime} \mathrm{S}, 72^{\circ} 0^{\prime} 23.39^{\prime \prime} \mathrm{W}\right)$. Two nurseries and 27 orchards of different Japanese plum cultivars, mainly 'Angeleno', 'Black Amber', 'Friar', 'Fortune', and 'Larry Anne', were examined. Samples of Prunus domestica subsp. domestica ' $\mathrm{D}$ 'Agen' and Prunus domestica subsp. italica 'Reina Claudia' were included (Table 1). Symptoms were recorded and photographed.

\subsection{Isolation and Purification}

In the laboratory, bark was removed from the samples, and $0.5 \mathrm{~cm}$ wooden pieces were cut from the margin of the discoloration area. These pieces were superficially disinfected using $10 \% v / v$ sodium hypochlorite ( $4.9 \%$ chlorine) for $4 \mathrm{~min}$ and aseptically plated on Petri plates containing acidified potato dextrose agar (APDA) (25\% potato dextrose agar (PDA), acidified with $0.2 \% v / v 85 \%$ lactic acid) (PDA Difco, Baltimore, MD, USA) and water agar (WA) (Winkler, Santiago, Chile). Plates were incubated at $25^{\circ} \mathrm{C}$ in darkness until mycelial development. Pure cultures were obtained by transferring hyphal tips to fresh PDA plates and incubating them at $25^{\circ} \mathrm{C}$.

\subsection{Identification and Characterization}

The identification was focused on isolates resembling C. purpureum. Fungal colonies showing white to beige cottony mycelia were preliminary selected $(n=95)$. Subsequently, the isolates were identified by their cultural characteristics after 7 and 14 days of incubation on PDA at $25{ }^{\circ} \mathrm{C}$. The morphology of the mycelia, presence of clamp connections, and morphometry of spores from pseudo-basidiocarps were determined using an optical microscope (Eclipse 80i, Nikon, Tokyo, Japan) and the software Nikon NIS-elements D2.30 (Tokyo, Japan).

Furthermore, representative isolates were identified by molecular means $(n=57)$. Pure cultures were incubated on PDA at $25^{\circ} \mathrm{C}$ for 7 days. Total nucleic acids were isolated from fresh mycelium using the CTAB method, and genomic DNA (20 ng) was amplified using APN 1 C. purpureum-specific primers (Table 2), following the protocols described 
by [3]. The PCR products $(20 \mu \mathrm{L})$ were analysed on $1.5 \%$ agarose gels, using a $1 \mathrm{~kb}$ DNA ladder (Maestrogen Inc., Xiangshan Dist., Hsinchu, Taiwan) as a molecular size standard. Electrophoresis was performed at $7.5 \mathrm{~V} / \mathrm{cm}$ for $1 \mathrm{~h}$, and gels were stained with ethidium bromide $(1 \mu \mathrm{g} / \mathrm{mL})$. Gels were visualized under UV light $(\lambda=365 \mathrm{~nm})$ transillumination (Clear View standard UV transilluminator, UK) and digitally recorded (PC2010, Cannon, Nagasaki, Japan).

Table 2. Primer sequences used in the molecular analysis. APN1 and APM22 are specific primers for Chondrostereum purpureum.

\begin{tabular}{cccccc}
\hline Primer & Target & Sense & Sequence $\left(5^{\prime}-\mathbf{3}^{\prime}\right)$ & TM $\left({ }^{\circ} \mathbf{C}\right)$ & Reference \\
\hline ITS1 & ITS & Forward & CTTGGTCATTTAGAGGAAGTAA & 51 & {$[45]$} \\
ITS4 & ITS & Reverse & TCCTCCGCTTATTGATATGC & 52 & {$[45]$} \\
APN1-F & IGS & Forward & GCACGGAGAAGGAGAAGATTGGCT & 61.6 & {$[14]$} \\
APN1-R & IGS & Reverse & TTTCGGACTTTTGGGGCTCATTTCG & 64.7 & {$[14]$} \\
APM22D13F & SCAR & Forward & GGGGTGACGAGGACGACGGTG & 63.2 & {$[14]$} \\
APM22D13R & SCAR & Reverse & GGGGTGACGACATTATACTGCAGGTAGTAG & 60 & {$[14]$} \\
\hline
\end{tabular}

The internal transcribed spacer of four representative isolates selected from different host cultivars and collection localities was amplified using ITS1 and ITS4 primers (Table 1) and GoTaq ${ }^{\circledR}$ Green Master Mix 2X (Promega, Madison, WI, USA). The PCR conditions were an initial denaturation at $94^{\circ} \mathrm{C}$ for $5 \mathrm{~min}$, followed by 30 cycles of denaturation at $94{ }^{\circ} \mathrm{C}$ for $1 \mathrm{~min}$, annealing at $52{ }^{\circ} \mathrm{C}$ for $1.5 \mathrm{~min}$, and extension at $72{ }^{\circ} \mathrm{C}$ for $2 \mathrm{~min}$. Fungal DNA was quantified using a fluorometer (Qubit 2.0, Invitrogen, Carlsbad, CA, USA). Electrophoresis, staining, and visualization were conducted as described for APN1 gels. The PCR products were purified and sequenced by Macrogen (Macrogen Inc., Seoul, Korea), and the nucleotide sequences were assembled and edited using the Sequencher software version 5.4.6 (Gene Codes Corporation, Ann Arbor, MI, USA). Subsequently, sequences were compared with the GenBank database using the BLAST software (Basic Local Alignment Search Tool program), (National Center for Biotechnology Information (NCBI), Rockville Pike, Bethesda, MD, USA).

Furthermore, colonies showing different characteristics such as a dark colour were preliminary identified by the morphometry of their reproductive structures. Basidiomycete fungi, of which the colonies are similar to those of C. purpureum, were discriminated by the colony shape and density and also by their DNA amplification using APN1 species-specific primers [23].

\subsection{Pathogenicity}

Four representative isolates were inoculated on healthy 2-year-old nursery plants 'Angeleno'. Fresh cuts were aseptically performed on the main 1-year-old lateral branches (1-1.5 cm diameter). Cuts were inoculated with $0.7-\mathrm{cm}$-diameter mycelial plugs collected from growing colonies of C. purpureum representative isolates HMCi7, HMCi121, HMCi147, and HMCi148 and incubated on PDA for 7 days at $25^{\circ} \mathrm{C}$. Sterile agar was used for controls. The inoculum was covered with petroleum jelly and plastic film to prevent dehydration. Five plants were inoculated per treatment based on a completely randomized block design at the beginning of September 2019. Plants were incubated in a screenhouse for 65 days at an environmental temperature of $5-18{ }^{\circ} \mathrm{C}$ and were periodically monitored to observe the occurrence of foliar symptoms, of which the severity was recorded using a visual scale (Figure 2). After the incubation period, branches were cut and analysed in the laboratory. Branches were cut longitudinally, and necrotic symptoms were recorded. Small wood pieces $0.5 \mathrm{~cm}$ were cut from the necrotic margin and aseptically plated on APDA. The reisolated fungi were purified, following the protocol described above.

Genomic DNA was extracted from the reisolated fungi and amplified using C. purpureum SCAR species-specific primers [14] (Table 1). PCR conditions were those indicated by the authors. Electrophoresis, staining, and visualization were conducted as described 
above. Subsequently, banding patterns from the inoculated isolates were compared with the reisolated ones to confirm Koch's postulates.

\subsection{Silverleaf Effects on Plum}

To determine the Silverleaf effects on plum trees, water potential, fruit yield, and quality were measured in a 22-year-old orchard ('Angeleno') on Mariana 2624 rootstock, with planting distances of $4.5 \times 3 \mathrm{~m}$, located in the Maule Region ( $34^{\circ} 58^{\prime} 58.21^{\prime \prime} \mathrm{S}, 71^{\circ} 16^{\prime} 37.01^{\prime \prime} \mathrm{W}$ ), in the 2019 and 2020 harvest periods. Twenty healthy and 20 diseased trees were selected, homogeneous in their height and architecture, and located on four adjacent rows, to avoid topography and other differences among them. Each experimental unit consisted of two adjacent trees of the same treatment, with 10 replicates.

Trees were selected based on the absence of foliar silver symptoms for healthy ones and on the presence of them in diseased ones (Grade 3 or higher on the symptom severity scale) and were widespread throughout the canopy for diseased plants, meaning more than the $80 \%$ of the leaves had Silverleaf symptoms, from slightly to severely affected.

The Silverleaf foliar symptom visual severity scale (Grades 1-9) was devised using leaves from 'Angeleno' plum trees, naturally infected with C. purpureum, showing different levels of Silverleaf symptoms. Grades were assigned to the different foliar symptom visual intensities: 1 = healthy or apparently healthy leaf, 3 = epidermis starts detaching from the mesophyll and the colour is lighter than that in healthy leaves, $5=$ more than $75 \%$ of the leaf adaxial epidermis is detached from the mesophyll, and the leaf is beginning to look grey-silver, $7=100 \%$ of the epidermis is detached from the mesophyll, and the leaf is completely white-silver, $9=$ the epidermis peels off from the leaf, and the mesophyll begins to oxidize. Grades 2, 4, 6, and 8 indicate intermediate symptom severity between the previous and the following grade. Epidermis detachment on the leaf adaxial surface was confirmed using a Stereo Microscope at $15 \times$ (Olympus SZ61, Tokyo, Japan).

Additionally, the presence or absence of $C$. purpureum was confirmed through the amplification of DNA isolated from sawdust collected from the main trunk [3], using APN1-specific primers [14], following the previously described protocol.

\subsubsection{Water Potential}

Xylem potential was measured on diseased and healthy trees on 1 March 2019, and 10 March 2020 (about 3-6 days after harvest). For both periods, it was measured on lightexposed leaves (five leaves per plant), which were previously covered for $2 \mathrm{~h}$ to avoid sunlight. Xylem potential was measured using a Scholander-type pressure chamber (Model 615, PMS Instruments, Albany, NY, USA).

\subsubsection{Yield Assessment}

Fruit was harvested on 27 February 2019 and 4 March 2020, the same dates that producers harvested the orchard. Before harvesting the fruit from each selected healthy and diseased tree, 10 random fruits from one lateral representative branch of each tree were set aside for quality parameter analysis (see Section 4.5.3) in the laboratory. Subsequently, the remaining fruit of each tree was individually collected and weighed.

\subsubsection{Fruit Quality}

Quality parameters were measured on the 10 previously reserved fruit. The measured parameters were individual weight (g), cover colour (\%), and background colour (\%), based on a plum colour chart [54], calibre (polar and equatorial diameter measured using a digital calliper), titratable acidity measured by potentiometric titration with $\mathrm{NaOH} 0.1 \mathrm{~N}$ (Hanna, pH 211, Nușfalău, Romania) expressed as citric acid proportion (\%) (AOAC, 2000), pH, and soluble solids, measured with a digital refractometer (Brix degrees) (Atago, Pocket PALrefractometer, Japan). For firmness measurement, two cheeks per fruit were cut, and the firmness was measured using a manual firmness penetrometer (FT 327, Facchini, Alfonsine, Italy) inserted in an aluminium holder for penetrometers (Dimeri, Santiago, Chile). The 
probe diameter was $8 \mathrm{~mm}$. Media from both cheeks were subsequently analysed. The average of measurements $(n=10)$ was calculated for each parameter for further analysis.

\section{Experimental Design and Statistical Analyses}

The experimental unit consisted of two adjacent trees from the same treatment. The treatments were Silverleaf-diseased and healthy conditions, with 10 replicates from four rows in the orchard based on a randomized complete block design.

Fruit yield (total weight) was directly analysed, while for water potential, 10 samples (leaves) per plot were measured and averaged. Subsequently, averages of each plot were statistically analysed. For each fruit quality parameter, 20 samples (fruits) per plot were measured, and the averages were analysed.

Before testing for statistical significance, to detect differences between treatment means, normality and homoscedasticity were evaluated by the Shapiro-Wilk test, residual independence analysis, and graphical methods. When assumptions of normality and homoscedasticity were fulfilled, Student's $t$-test was used to compare healthy and diseased means of water potential, yield, and individual fruit weight.

Cover colour was analysed by Pearson's Chi-squared test, and fruit firmness and calibre by the Kruskal-Wallis test. The statistical analyses used depended on the nature of the data and distribution. Analyses were performed using InfoStat 2021 statistical software (Universidad Nacional de Córdoba, Córdoba, Argentina).

Author Contributions: Conceived the idea of the research, D.G.; scientific experiments design and methodology, D.G. and J.C.; Field surveys and collections, D.G., J.C. and M.I.; isolation, morphological characterization and pathogenicity tests, D.G. and M.I.; fungal sequencing, molecular detection and genetic characterization, J.C., physiological measurements, M.R.; yield assessment, D.G., J.C. and M.I.; fruit quality evaluations, C.H. and M.I.; writing and editing, D.G., J.C. and M.I.; critical review and editing, A.F. and J.B.; project administration and funding acquisition, J.B. All authors have read and agreed to the published version of the manuscript.

Funding: This research was supported by funding from The Research Council of Norway (project nr. 282257).

Data Availability Statement: Data is contained within the article.

Conflicts of Interest: The authors declare no conflict of interest.

\section{References}

1. Odepa, Estudios y Políticas Agrarias. Ministerio de Agricultura. Evolución de la Fruticultura Chilena en los Últimos 20 Años. Oficina de estudios y políticas Agrarias. 2021. Available online: https://www.odepa.gob.cl/rubros/frutas-frescas (accessed on 27 April 2021).

2. Gramaje, D.; Baumgartner, K.; Halleen, F.; Mostert, L.; Sosnowski, M.R.; Úrbez-Torres, J.R.; Armengol, J. Fungal trunk diseases: A problem beyond grapevines? Plant Pathol. 2016, 65, 355-356. [CrossRef]

3. Grinbergs, D.; Chilian, J.; Carrasco-Fernandez, J.; France, A.; Moya-Elizondo, E.; Gerding, M. A PCR-based method for the rapid detection of Chondrostereum purpureum in apple. Plant Dis. 2020, 104, 702-707. [CrossRef]

4. France, A.; Grinbergs, D.; Carrasco, J. First detection of Silverleaf (Chondrostereum purpureum) on rabbiteye blueberry (Vaccinium ashei) and disease damages. Acta Hortic. 2017, 1180, 277. [CrossRef]

5. Gramaje, D.; Agustí-Brisach, C.; Pérez-Sierra, A.; Moralejo, E.; Olmo, D.; Mostert, L.; Damm, U.; Armengol, J. Fungal trunk pathogens associated with wood decay of almond trees on Mallorca (Spain). Persoonia 2012, 28, 1-13. [CrossRef] [PubMed]

6. Cha, J.; Lee, S.; Chun, K.; Lee, S.; Ohga, S. Armillaria root rot caused by Armillaria Tabescens on Prunus Salicina in a Korean garden. J. Fac. Agric. Kyushu Univ. 2009, 54, 1273-1277.

7. Ko, Y.; Yao, K.; Chen, C.; Liu, C.; Maruthasalam, S.; Lin, C. First report of gummosis disease of plum (Prunus salicina) caused by a Botryosphaeria sp. in Taiwan. Plant Dis. 2008, 92, 483. [CrossRef] [PubMed]

8. Mojeremane, K.; Lebenya, P.; du Plessis, I.; van der Rijst, M.; Mostert, L.; Armengol, J.; Halleen, F. Cross pathogenicity of Neofusicoccum australe and Neofusicoccum stellenboschiana on grapevine and selected fruit and ornamental trees. Phytopathol. Mediterr. 2020, 59, 581-593. [CrossRef]

9. Damm, U.; Crous, P.; Fourie, P. Afissitunicate ascus mechanism in the Calosphaeriaceae, and novel species of Jattaea and Calosphaeria on Prunus wood. Persoonia 2008, 20, 39-52. [CrossRef]

10. Damm, U.; Crous, P.; Fourie, P. Botryosphaeriaceae as potential pathogens of Prunus species in South Africa, with descriptions of Diplodia africana and Lasiodiplodia plurivora sp. nov. Mycologia 2007, 99, 664-680. [CrossRef] 
11. Li, Q.; Tang, L.; Sun, W.; Huang, S.; Guo, T.; Mo, J.; Fan, M.; Zhang, A.; Hsiang, T. First report of stem canker and dieback caused by Neofusicoccum parvum on plum in Guangxi, Southern China. Plant Dis. 2019, 103, 2952. [CrossRef]

12. Damm, U.; Mostert, L.; Crous, P.; Fourie, P. Novel Phaeoacremonium species associated with necrotic wood of Prunus trees. Persoonia 2008, 20, 87-102. [CrossRef]

13. Ramsfield, R.D. Risk assessment of inundative biological control with Chondrostereum purpureum in New Zealand. N. Z. J. For. Sci. 2006, 36, 11-20.

14. Becker, E.; Ball, L.; Hintz, W. PCR Based genetic markers for detection and infection frequency analysis of the biocontrol fungus Chondrostereum purpureum on Stika Alder and Trembling Aspen. Biol. Control. 1999, 15, 71-80. [CrossRef]

15. Becker, E.; Shamoun, S.; Hinz, W. Efficacy and environmental fate of Chondrostereum purpureum used as a biological control for red alder (Alnus rubra). Biol. Control. 2005, 33, 269-277. [CrossRef]

16. Shamoun, S. Application of biological control to vegetation management in forestry. In Proceedings of the $X$ International Symposium on Biological Control of Weeds, Bozeman, MT, USA, 4-14 July 1999; pp. 87-96.

17. Hamberg, L.; Saksa, T.; Hantula, J. Role of Chondrostereum purpureum in biocontrol of trees. Appl. Microbiol. Biotechnol. 2021, 105, 431-440. [CrossRef] [PubMed]

18. Bus, V.; Spiers, A.; Brewster, D.; Hofstee, M. Preliminary screening of apple germplasm for resistance to Silverleaf infection. N. Z. J. Crop Hortic. Sci. 1996, 24, 1-6. [CrossRef]

19. Setliff, E.C. The wound pathogen Chondrostereum purpureum, its history and incidence on trees in North America. Austral. J. Bot. 2002, 50, 645-651. [CrossRef]

20. Willoughby, I.H.; Seier, M.K.; Stokes, V.J.; Thomas, S.E.; Varia, S. Synthetic herbicides were more effective than a bioherbicide based on Chondrostereum purpureum in reducing resprouting of Rhododendron ponticum, a host of Phytophthora ramorum in the UK. Forestry 2015, 88, 336-344. [CrossRef]

21. Hamberg, L.; Hantula, J. The efficacy of six elite isolates of the fungus Chondrostereum purpureum against the sprouting of European aspen. J. Environ. Manag. 2016, 171, 217-224. [CrossRef]

22. Merlet, L.; Wiseman, M.; Serdani, M.; Putnam, M.L. First report of Silver Leaf caused by Chondrostereum purpureum on Vaccinium corymbosum in Oregon. Plant Dis. 2018, 102, 2041. [CrossRef]

23. Grinbergs, D.; Chilian, J.; Lisboa, K.; France, A. First report of Silverleaf disease caused by Chondrostereum purpureum on murta (Ugni molinae Turcz.) in Chile. Plant Dis. 2019, 103, 2140. [CrossRef]

24. Spiers, A.G.; Hopcroft, D.H. Factors affecting Chondrostereum purpureum infection of Salix. Eur. J. For. Pathol. 1988, 18, 257-278. [CrossRef]

25. Spiers, A.G.; Brewster, D. Evaluation of chemical and biological treatments for control of Chondrostereum purpureum infection of pruning wounds in willows, apples, and peaches. N. Zeal. J. Crop Hort. 1997, 25, 19-31. [CrossRef]

26. Spiers, A.; Edwards, W.; Hopcroft, D. Effects of Silverleaf infection on ultrastructure of foliage of Prunus, Rosa, and Populus. N. Z. J. Bot. 1987, 25, 411-423. [CrossRef]

27. Simpson, R.M.; Van Hekezen, R.; Van Lune, F.; Brewster, D.; Spiers, A.G. Extracellular enzymes of Chondrostereum purpureum, causal fungus of Silverleaf disease. N. Z. Plant Prot. 2001, 54, 202-208. [CrossRef]

28. Cloete, M.; Fourie, P.; Damm, U.; Crous, P.; Mostert, L. Fungi associated with die-back symptoms of apple and pear trees, a possible inoculum source of grapevine trunk disease pathogens. Phytopathol. Mediterr. 2011, 50, 176-190. [CrossRef]

29. Ozgonen, H.; Erkilic, A.; Baloglu, S. First report of Chondrostereum purpureum causing Silverleaf disease of apricot (Prunus armeniaca) in Malatya, Turkey. N. Z. J. Crop Hortic. Sci. 2006, 34, 357. [CrossRef]

30. Børve, J.; Ippolito, A.; Tanovic, B.; Michalecka, M.; Sanzani, S.M.; Ponitowska, A.; Mari, M.; Hrustic, J. Fungal diseases. In Cherries. Botany, Production and Uses; Quero-García, J., Iezzoni, A., Pulawska, J., Lang, G.A., Eds.; CABI: Wallingford, CT, UK, 2017; pp. 338-364.

31. Spiers, A.; Brewster, D.; Bus, V.; Hopcroft, H. Seasonal variation in susceptibility of xylem tissue of Malus, Pyrus, Prunus, and Salix species to Chondrostereum purpureum in New Zealand. Mycol. Res. 1998, 102, 881-890. [CrossRef]

32. Ogawa, J.; English, H. Diseases of Temperate Zone Tree Fruit and Nut Crops; University of California: Oakland, CA, USA, 1991; Volume 3345, 461p.

33. Pearce, R.B.; Sumer, S.; Doran, S.J.; Carpenter, T.A.; Hali, L.D. Non-invasive imaging of fungal colonization and host response in the living sapwood of sycamore (Acer pseudoplatanus L.) using nuclear magnetic resonance. Physiol. Mol. Plant Path. 1994, 45, 359-384. [CrossRef]

34. Vartiamäki, H.; Hantula, J.; Uotila, A. Susceptibility of silver birch pruning wounds to infection by white-rot fungus (Chondrostereum purpureum), a potential bioherbicide. Silva Fenn. 2009, 43, 537-547. [CrossRef]

35. Senda, M.; Narita, T.; Akada, S.; Okuno, T.; Miyairi, K. Characterization of an endopolygalacturonase gene cppgl from phytopathogenic fungus Chondrostereum purpureum. J. Gen. Plant Pathol. 2001, 67, 41-44. [CrossRef]

36. Bishop, G.C. Studies on Silver Leaf Disease of Stone and Pome Fruit Trees. Ph.D. Thesis, University of Adelaide, Adelaide, Australia, 1978; 128p.

37. Głowacka, A.; Rozpara, E. Evaluation of several dessert cultivars of plum, new under climatic conditions of Poland. Hort. Sci. (Prague) 2017, 44, 126-132. [CrossRef]

38. Kaufmane, E.; Grâvîte, I.; Ikase, L. Plum research and growing in Latvia. Proc. Latv. Acad. Sci. Sect. B 2019, 73, 195-206. [CrossRef] 
39. Børve, J.; Talgø, V.; Stensvand, A. Silver Leaf in Norwegian Prunus domestica Plum Orchards. In Proceedings of the IOBC/WPRS Working Groups: Pheromones and Other Semiochemicals in IP \& Integrated Protection of Fruit Crops, PheroFIP 2019, Lisbon, Portugal, 20-25 January 2019; p. 219.

40. Atkinson, J.D. Diseases of Tree Fruits in New Zealand; Bulletin 81; Department of Scientific and Industrial Research: Auckland, New Zealand, 1971; 406p.

41. Bien, S.; Damm, U. Prunus trees in Germany-A hideout of unknown fungi? Mycol. Prog. 2020, 19, 667-690. [CrossRef]

42. Espargham, N.; Mohammadi, H.; Gramaje, D. A survey of trunk disease pathogens within Citrus trees in Iran. Plants 2020, 9 , 754. [CrossRef]

43. Bertsch, C.; Ramirez-Suero, M.; Magnin-Robert, M.; Larignon, P.; Chong, J.; Abou-Mansour, E.; Spagnolo, A.; Clément, C.; Fontaine, F. Grapevine trunk diseases: Complex and still poorly understood. Plant Pathol. 2013, 62, 243-265. [CrossRef]

44. Spiers, A.; Brewster, D.; Slade, A.; Gardiner, S. Characterization of New Zealand isolates of Chondrostereum purpureum with regard to morphology, growth, pathogenicity and RAPD bandings patterns. Mycol. Res. 2000, 104, 395-402. [CrossRef]

45. White, T.J.; Bruns, T.; Lee, S.; Taylor, J. Amplification and direct sequencing of fungi ribosomal RNA genes for phylogenetics. In PCR Protocols. A Guide to Methods and Applications: 315-322; Academic Press: San Diego, CA, USA, 1990.

46. France, A.; Santelices, C.; Buddie, A.; Kirk, P. Silverleaf: First worlwide report of a new and harmful disease on blueberry. Acta Hortic. (ISHS) 2009, 810, 341-344. [CrossRef]

47. Petit, A.N.; Vaillant, N.; Boulay, M.; Clément, C.; Fontaine, F. Alteration of photosynthesis in grapevines affected by esca. Phytopathology 2006, 96, 1060-1066. [CrossRef] [PubMed]

48. Fontaine, F.; Pinto, C.; Vallet, J.; Clément, C.; Gomes, A.; Spagnolo, A. The effects of grapevine trunk diseases (GTDs) on vine physiology. Eur. J. Plant Pathol. 2015. [CrossRef]

49. Hamberg, L.; Vartiamäki, H.; Hantula, J. Breeding Increases the Efficacy of Chondrostereum purpureum in the Sprout Control of Birch. PLoS ONE 2015, 10, e0117381. [CrossRef] [PubMed]

50. Grinbergs, D.; Chilian, J.; Padilla, N.; Reyes, M.; France, A.; Gerding, M.; Ernesto, A. Moya-Elizondo.. Endophytic microorganisms associated with reversion of Silverleaf disease symptoms in apple. Phytopathology 2021. [CrossRef] [PubMed]

51. Xing, J.; Li, P.; Zhang, Y.; Li, J.; Liu, Y.; Lachenbruch, B.; Su, X.; Zhao, J. Fungal pathogens of canker disease trigger canopy dieback in poplar saplings by inducing functional failure of the phloem and cambium and carbon starvation in the xylem. Physiol. Mol. Plant Path. 2020, 112, 101523. [CrossRef]

52. Bailey, B.; Bae, H.; Strem, M.; Crozier, J.; Thomas, S.; Samuels, G.; Vinyard, B.; Holmes, K. Antibiosis, mycoparasitism, and colonization success for endophytic Trichoderma isolates with biological control potential in Theobroma cacao. Biol. Control 2008, 46, 24-35. [CrossRef]

53. Grinbergs, D.; France, A.; Chilian, J. Silverleaf disease in apple orchards: Understanding and preventing an increasing problem. In Proceedings of the 11th International IOBC-WPRS Workshop on Pome Fruit Diseases, Jurmala, Latvia, 26-30 June 2017; Stensvand, A., Lennox, C., Wenneker, M., Morocko-Bicevska, I., Rancane, R., Eds.; International Organization for Biological and Integrated Control of Noxious Animals and Plants, West Palearctic Regional Section (IOBC-WPRS): Darmstadt, Germany, 2018; Volume 138, p. 100.

54. Rivero, M.; Quiroga, M.; Gonzalez, O.; Moraga, L. Plum postharvest manual. INTA, Instituto de Investigaciones Agropecuarias. 2013. Available online: https:/ /inta.gob.ar/sites/default/files/script-tmp-ficha_n_1_-_cosecha.pdf (accessed on 27 April 2021). 